\title{
Comparative Evaluation of Prooxidant/Antioxidant Balance in Seed Progeny of Plantago major L. from Radioactively and Chemically Contaminated Areas
}

\author{
Nadezhda S. Shimalina*, \\ Natal'ya A. Orekhova and Vera N. Pozolotina \\ Institute of Plant and Animal Ecology \\ Ural Branch of the RAS \\ Ekaterinburg, Russian Federation
}

Received 21.02.2021, received in revised form 15.04.2021, accepted 12.05.2021, published online 16.08.2021

\begin{abstract}
There are many studies addressing plant responses to radioactive and chemical contamination of soils, but few works have been devoted to comparison of biological effects in the areas affected by these human-induced factors. Ionizing radiation and heavy metals have different mechanisms of interaction with biota. Both factors, however, are capable of increasing the generation of reactive oxygen species, which cause enzyme malfunction and cell structure damage. The efficiency of antioxidant systems plays an important role in plant resistance to these impacts. The present study offers a comparative evaluation of prooxidant/antioxidant balance in seed progeny of Plantago major L. growing in the East Ural Radioactive Trace (EURT), in the zone affected by operation of the Karabash Copper Smelter (KCS), and in the reference sites. Lipid peroxidation was assessed by determining malondialdehyde. Evaluation of the antioxidant system was based on the activities of superoxide dismutase, catalase, and total peroxidase, and on the content of low-molecular-weight antioxidants. The study showed that the prooxidant and antioxidant statuses of seed progeny of $P$. major from the contaminated sites were different from the reference samples and from each other. The pooled EURT sample exhibited a prooxidant shift relative to the reference samples, i. e. not only malondialdehyde but also activities of superoxide dismutase and catalase and the content of low-molecular-weight antioxidants were higher than in the reference samples. Malondialdehyde content in seedlings from the KCS zone did not differ from the reference values; superoxide dismutase and catalase activities were decreased whereas peroxidase activity was higher compared to the activities of these enzymes in the reference samples. Thus, the differences in the plant adaptive responses to ionizing radiation and heavy metals are caused by the dissimilarities in the induction of reactive oxygen species.
\end{abstract}

(C) Siberian Federal University. All rights reserved

This work is licensed under a Creative Commons Attribution-NonCommercial 4.0 International License (CC BY-NC 4.0).

* Corresponding author E-mail address: nadia_malina@mail.ru

ORCID: 0000-0003-1458-496X (Shimalina N.); 0000-0002-8415-3201 (Orekhova N.); 0000-0001-6918-7756 (Pozolotina V.) 
Keywords: Plantago major, oxidative stress, antioxidant protection system, radioactive contamination, heavy metal contamination.

Acknowledgements. This study was performed within the frameworks of state contract with the Institute of Plant and Animal Ecology, Ural Branch, Russian Academy of Sciences.

\title{
Сравнительная оценка про- и антиоксидантного статуса семенного потомства Plantago major L.
} из зон радиоактивного и химического загрязнения

\author{
Н.С. Шималина, \\ Н.А. Орехова, В.Н. Позолотина \\ Институт экологии растений и животных УрО РАН \\ Российская Федерация, Екатеринбург
}

\begin{abstract}
Аннотация. Ответные реакции растений на действие радиации и тяжелых металлов изучены в многочисленных исследованиях, но работ по сравнению биологических эффектов в зонах влияния этих техногенных факторов известно немного. Радиация и тяжелые металлы имеют разные механизмы взаимодействия с биотой, но оба фактора способны усиливать образование активных форм кислорода, вызывающих нарушение работы ферментов и повреждение клеточных структур, поэтому важную роль в устойчивости растений к этим воздействиям играет эффективность работы антиоксидантных систем. Дана сравнительная оценка про- и антиоксидантного статуса семенного потомства Plantago major L. из популяций, произрастающих в головной части Восточно-Уральского радиоактивного следа (ВУРС) и в зоне влияния Карабашского медеплавильного завода (КМЗ), а также на фоновых территориях. Интенсивность процессов перекисного окисления липидов определяли по концентрации малонового диальдегида. Работу антиоксидантной системы оценивали по активности трех ферментов: супероксиддисмутазы, каталазы и общей пероксидазной активности, а также по суммарному содержанию низкомолекулярных антиоксидантов. Установлено, что прои антиоксидантные статусы семенного потомства подорожника из техногенных зон отличны от фоновых выборок и различаются между собой. У проростков из зоны ВУРСа зафиксирован прооксидантный сдвиг, т. е. при высоком содержании малонового диальдегида была повышена активность супероксиддисмутазы и каталазы, а также содержание низкомолекулярных антиоксидантов по сравнению с фоновыми растениями. У проростков из зоны КМЗ содержание малонового диальдегида не отличалось от фонового, активности супероксиддисмутазы и каталазы были снижены, а пероксидазы повышена. Таким образом, специфика адаптивных
\end{abstract}

$$
-307-
$$


ответов растений на действие радиации и тяжелых металлов формируется за счет различий в индукции активных форм кислорода.

Ключевые слова: Plantago major, окислительный стресс, система антиоксидантной защиты, радиоактивное загрязнение, загрязнение тяжелыми металлами.

Благодарности. Работа выполнена в рамках государственного задания Института экологии растений и животных УрО РАН.

Цитирование: Шималина, Н. С. Сравнительная оценка про- и антиоксидантного статуса семенного потомства Plantago major L. из зон радиоактивного и химического загрязнения / Н. С. Шималина, Н. А. Орехова, В.Н. Позолотина // Журн. Сиб. федер. ун-та. Биология, 2021. 14(3). С. 306-317. DOI: 10.17516/1997-1389-0358

\section{Introduction}

A substantial amount of research has been focused on the effects of ionizing radiation (Esnault et al., 2010; Møller, Mousseau, 2015; Caplin, Willey, 2018) and heavy metals (Titov et al., 2014; Zvereva et al., 2010; Sharma, Agrawal, 2005; Fischer et al., 2013) on natural plant populations, but few studies have been devoted to comparison of biological effects in plants growing in the areas affected by different anthropogenic factors (Pozolotina et al., 2012; 2016). Ionizing radiation and heavy metals differ in their physical nature and have different mechanisms of interaction with biota at the molecular level. However, both factors can increase the generation of reactive oxygen species (ROS) and induce oxidative stress; therefore, the efficiency of the antioxidant system plays an important role in plant resistance to anthropogenic stressors (Khramova et al., 2006; Sharma et al., 2012; Morozova et al., 2016; Volkova et al., 2017; Gudkov et al., 2019). Thus, the adaptive response of plants may vary depending on the type of stressor. The aim of this study was to assess and compare the prooxidant/antioxidant status in seed progeny of Plantago major L. plants that have been growing for a long time in radioactively or chemically contaminated sites and in the reference areas.

\section{Materials and methods}

The greater plantain (P. major) is a perennial herbaceous polycarpic plant of the Plantaginaceae family. This species is diploid $(2 n=12)$, reproduces mainly by seeds; humans unintentionally participate in the spread of plants (anthropochory) (Ontogenetic atlas of medicinal plants, 1997). The study was carried out in regions with different types of industry-induced pollution: the East Ural Radioactive Trace (EURT), the area affected by the Karabash Copper Smelter (KCS) emissions, and reference areas.

The EURT was formed because of an accident at the «Mayak» Production Association on September 29, 1957: the explosion of the tank with radioactive waste. The main pollutant is ${ }^{90} \mathrm{Sr}$, whose half-life is 28.8 years (Nikipelov et al., 1990). Even 60 years after the EURT formation, densities of soil contamination by ${ }^{90} \mathrm{Sr}$ along the central axis of the trace exceed the background level by 2-4 orders of magnitude (Molchanova et al., 2014). Three sites were selected along the EURT central axis (Fig. 1). Absorbed dose rates for P. major maternal plants were calculated using the ERICA Tool and taking into account the contributions of ${ }^{90} \mathrm{Sr},{ }^{137} \mathrm{Cs}$, and ${ }^{239,240} \mathrm{Pu}$ and the natural background radiation (Karimullina et al., 2018). Absorbed dose rates within the EURT ranged from 19.1 to 157.1 $\mu \mathrm{Gy} / \mathrm{h}$ (background value $=0.109 \mu \mathrm{Gy} / \mathrm{h}$ ), which 


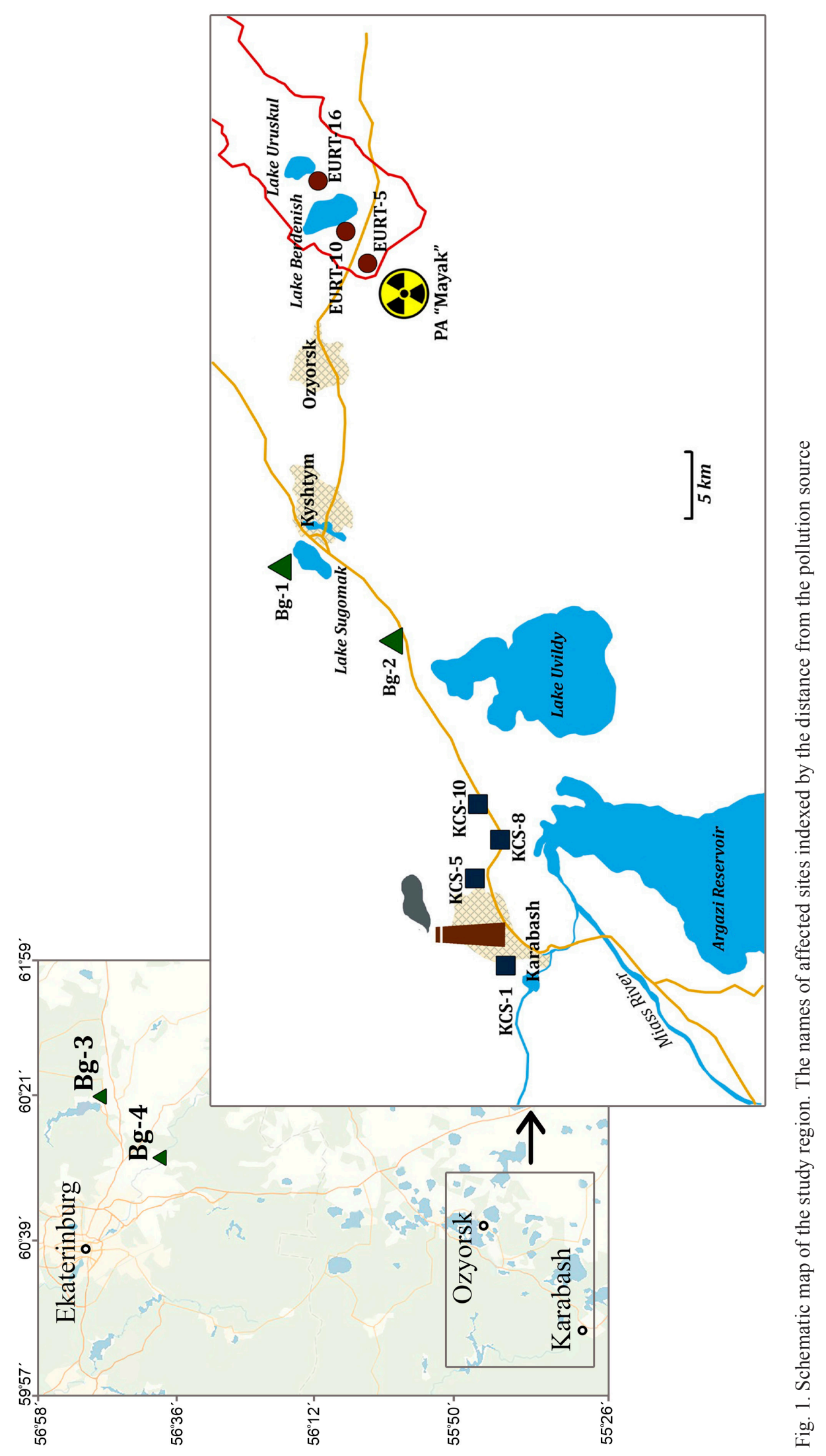


corresponded to the low-dose range for plant organisms (Garnier-Laplace et al., 2013).

The Karabash Copper Smelter was put into operation in 1910, with no equipment for treatment of atmospheric emissions and wastewater. Emissions of pollutants into the atmosphere were at their maximum levels in the 1960-1970s. The main components of the smelter emissions were sulfur dioxide and dust containing heavy metal (HM) particles (Stepanov et al., 1992). The KCS operations were suspended from 1989 to 1997, and emissions have considerably decreased after reconstruction (Stepanov et al., 1992; Chernen'kova, 2002). Nevertheless, the amount of heavy metals $(\mathrm{Zn}, \mathrm{Cu}, \mathrm{Pb}, \mathrm{Cd})$ accumulated in the soils is still very high, exceeding the background level by at least one order of magnitude. The soil in the contaminated area has increased acidity $\left(\mathrm{pH}_{\mathrm{H} 2 \mathrm{O}}=5.8\right.$, with the background $\left.\mathrm{pH}=6.4\right)$ (Stepanov et al., 1992; Smorkalov, Vorobeichik, 2011). Four sites were selected in the chemically contaminated area at different distances from the KCS (Fig. 1). The toxic load indices at the KCS study sites were higher than the average background value by factors of 5.2-41.8 (Shimalina et al., 2017).

Reference sites were located outside the radioactive and chemically polluted areas in the Sverdlovsk and Chelyabinsk Regions (Fig. 1); detailed descriptions of test sites are given in (Shimalina et al., 2017; 2018). All sampling sites were located at the sides of rarely used country roads, on which transects from 0.5 to $1 \mathrm{~km}$ in length were laid. A pooled sample of seeds from 40-50 plants was collected from each site. P. major seeds were cultivated for 21 days at $24{ }^{\circ} \mathrm{C}$ and 12-hour photoperiod in filter paper rolls placed in glass vessels with distilled water. The grown seedlings were used for biochemical analyses. The prooxidant status was assessed by the concentration of the secondary products of lipid peroxidation (LPO), the main of which is malondialdehyde (MDA). The MDA content was determined using a reaction medium consisting of a solution of trichloroacetic and thiobarbituric acids; absorbance measurements were performed at $532 \mathrm{~nm}$ reference wavelength (Buege, Aust, 1978). Antioxidant status was evaluated by the activity of three enzymes: superoxide dismutase (SOD, EC1.15.1.1), catalase (CAT, EC1.11.1.6), and peroxidase (POX, EC1.11.1.7). Dried seedlings were homogenized in a Tris-HCl pH 7.4 buffer solution. The homogenate was centrifuged for 10 $\min \left(\mathrm{t}=+4{ }^{\circ} \mathrm{C}\right)$. The SOD activity was assessed at $560 \mathrm{~nm}$ by inhibition of the photochemical formation of a colored reduced product of nitro blue tetrazolium with the participation of riboflavin and $L$-methionine (Giannopolitis, Ries, 1977). The CAT activity was measured at $410 \mathrm{~nm}$ by the intensity of the yellow color formed in the reaction of hydrogen peroxide with molybdenum salts (Góth, 1991). The POX activity was determined at $610 \mathrm{~nm}$ by the decrease in the color intensity of the reaction mixture upon indigo carmine oxidation by hydrogen peroxide (Popov, Neřkovska, 1971). Soluble protein content determination was based on the qualitative reaction with the Coomassie Brilliant Blue G250 dye (Kruger, 2009). Measurements of MDA and protein amounts and enzyme activities were carried out using a SpectraMax Plus 384 microplate spectrophotometer (Molecular Devices, U.S.A.). Also, total low-molecularweight antioxidants (LMWA) in seedlings were determined. The determination of total LMWA was based on LMWA oxidation with iron chloride (III) (Ermakov et al., 1987); absorbance measurements were performed using a DU-650 spectrophotometer (Beckman Coulter, U.S.A.) at $510 \mathrm{~nm}$ reference wavelength.

Data analysis was performed using the criteria of nonparametric statistics (MannWhitney $U$-test, $H$-test - Kruskal-Wallis rank analysis of variance, Dunn test). For multivariate comparison of biochemical data, the principal 
component method was used. Data analysis was performed with the STATISTICA 10.0 (StatSoft Inc., 2011) software.

\section{Results}

Differences in the biochemical status parameters of seedlings were insignificant between three samples from the EURT: MDA $\left(H_{(2 ; 21)}=3.17, p=0.205\right) ; \operatorname{SOD}\left(H_{(2 ; 21)}=3.36\right.$, $p=0.186) ; \operatorname{CAT}\left(H_{(2 ; 21)}=2.42, p=0.297\right) ; \mathrm{POX}$ $\left(H_{(2 ; 21)}=2.42, p=0.297\right)$. Similarly, there were no differences between four local populations from the KCS: MDA $\left(H_{(3 ; 25)}=2.72, p=0.436\right)$; $\operatorname{SOD}\left(H_{(3 ; 25)}=5.52, p=0.137\right) ; \operatorname{CAT}\left(H_{(3 ; 25)}=5.24\right.$, $p=0.155) ; \operatorname{POX}\left(H_{(3 ; 25)}=5.67, p=0.129\right)$. No significant differences were found between the parameters of the reference samples of $P$. major: $\operatorname{MDA}\left(H_{(2 ; 15)}=3.24, p=0.198\right) ; \operatorname{SOD}\left(H_{(2 ; 15)}=1.38\right.$, $p=0.501)$; CAT $\left(H_{(2 ; 15)}=5.27, p=0.071\right)$; POX $\left(H_{(2 ; 15)}=2.49, p=0.287\right)$. Therefore, for further analysis, the samples were pooled within the EURT, KCS, and reference sites.

The MDA content in P. major seedlings from the EURT sites was significantly increased compared to the reference values $(228 \%$ of the reference values; $U$-test, $n=15-21, p<0.001)$. In the KCS samples, the MDA content did not differ from the reference values ( $U$-test, $n=15-25$, $p=0.276)$. Comparison of the EURT and KCS samples revealed significant differences in the MDA content ( $U$-test, $n=21-25, p=0.016$ ) and SOD, CAT, and POX activities ( $U$-test, $n=21-25$, $p<0.001)$.

P. major samples from the EURT sites significantly differed from the reference ones in enzyme activity: the SOD and CAT activities were increased (270 \% of the activity in the reference samples; $U$-test, $p<0.001$, and $199 \%$; $U$-test, $p=0.040$, respectively) and POX activity, on the contrary, was lower than in the reference samples (44\%; $U$-test, $p=0.011$ ). The enzyme activity of the KCS samples also significantly differed from the enzyme activity of the reference samples. Seedlings from the KCS sites showed a decreased SOD activity ( $60 \%$ of the activity in the reference samples; $U$-test, $p=0.029)$, a decreased CAT activity (33\%; $U$-test, $p<0.001)$, and a higher POX activity (122\%; $U$-test, $p<0.001)$. Thus, in seedlings from the EURT sites, MDA content and SOD and CAT activities were higher and POX activity was lower compared to the samples from both the KCS and reference sites.

Multivariate comparison of biochemical data by the method of principal components (Fig. 2) showed that point projections of samples from contaminated and reference sites partially overlapped with each other for the first principal component, PC-1. This component explained $72.7 \%$ of intergroup variance, its value was based on the correlation with the activity of SOD ( $\beta=0.98)$, CAT $(\beta=0.99)$, and POX $(\beta=-0.98)$. The EURT samples were more isolated for PC-2 (it explained $25.5 \%$ of variance), where the main contribution to intergroup variability was made by the MDA value $(\beta=0.99)$.

The prooxidant/antioxidant index (PAI), calculated as the MDA/(SOD+CAT+POX) ratio, was used as the integrated indicator reflecting the general level of functioning of the antioxidant system components. Comparison of PAI values (Fig. 3) suggested the presence of a significant prooxidant shift in the EURT samples relative to the reference ( $331 \%, U$-test, $n=15-21, p<0.001$ ) and KCS samples $(510 \%, U$-test, $n=15-25$, $p<0.001)$. The results indicated that under these conditions of enzymatic protection, which deactivates reactive oxygen species, the rate of accumulation of secondary lipid peroxidation products in the affected local populations of the EURT was 3 and 5 times higher than in the reference and KCS samples, respectively. Another type of the prooxidant/antioxidant ratio was noted in seedlings from the KCS sites: no significant differences were found between the 


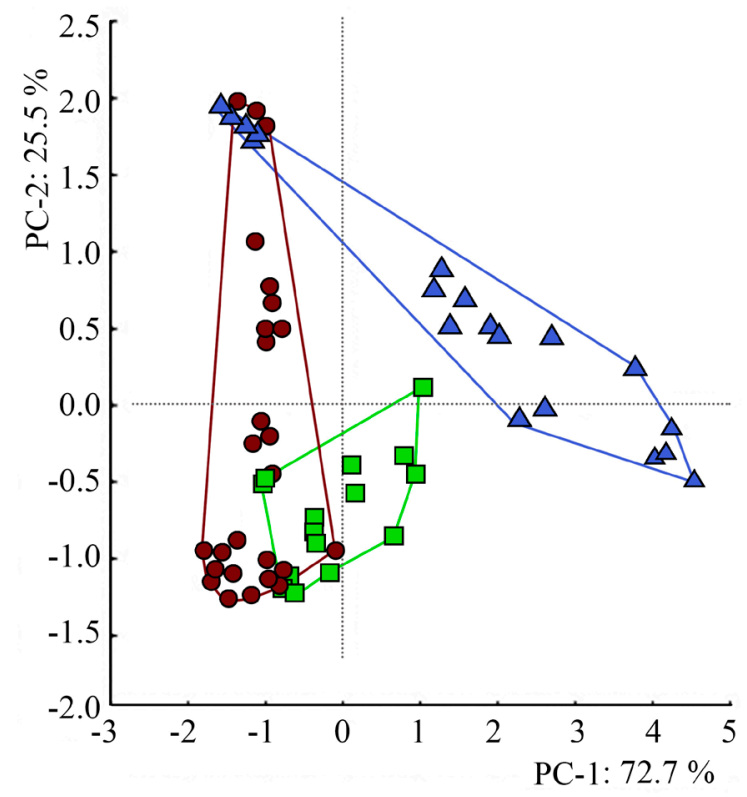

Fig. 2. Arrangement of reference, KCS and EURT samples in the plane of the two principal components formed by biochemical parameters: PC-1 - antioxidant enzymes; PC-2 - MDA; green squares - reference samples; red circles - KCS; blue triangles - EURT

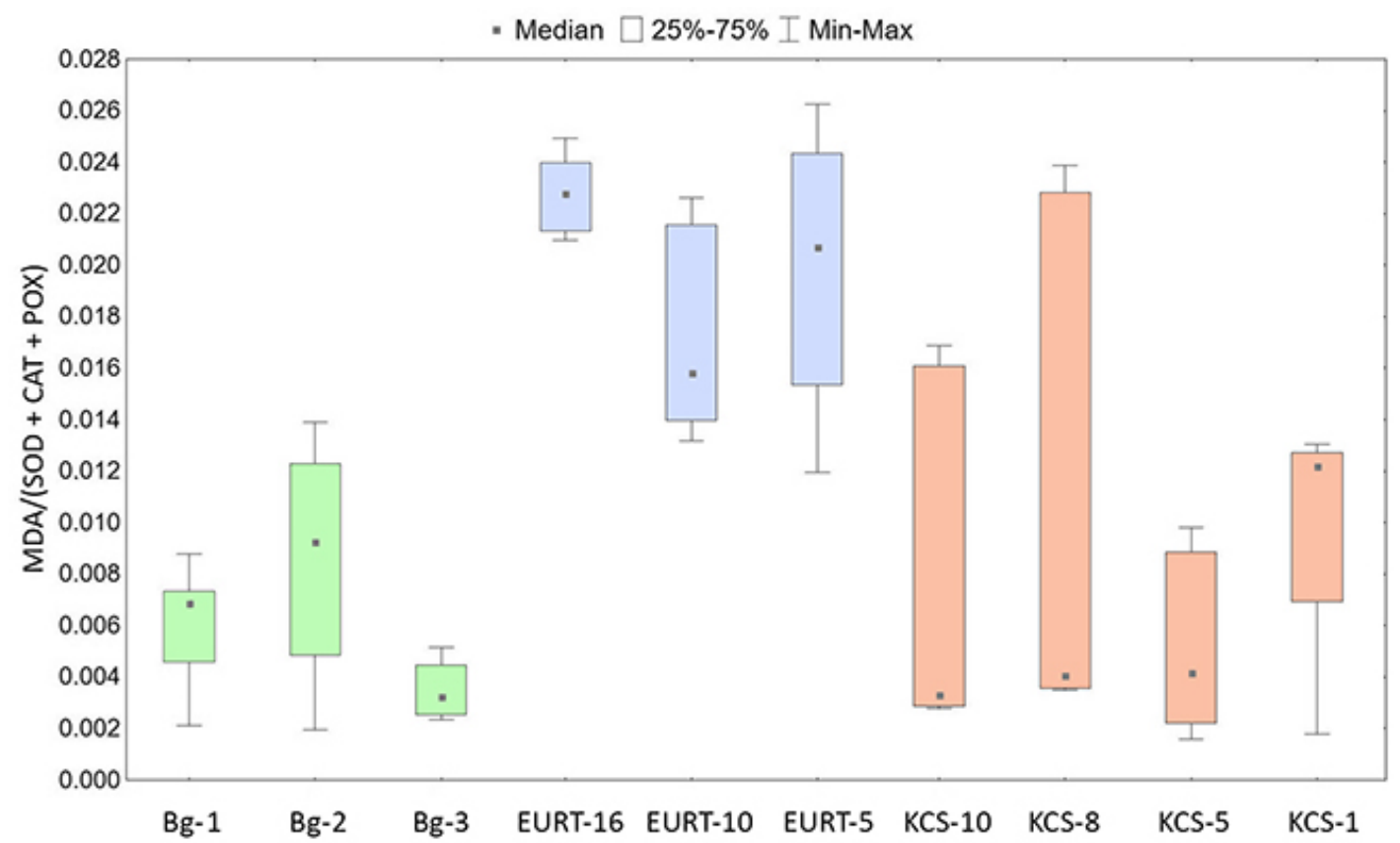

Fig. 3. Prooxidant/antioxidant index $(\mathrm{MDA} /(\mathrm{SOD}+\mathrm{CAT}+\mathrm{POX}))$ in $P$. major seedlings from the reference, KCS and EURT samples 


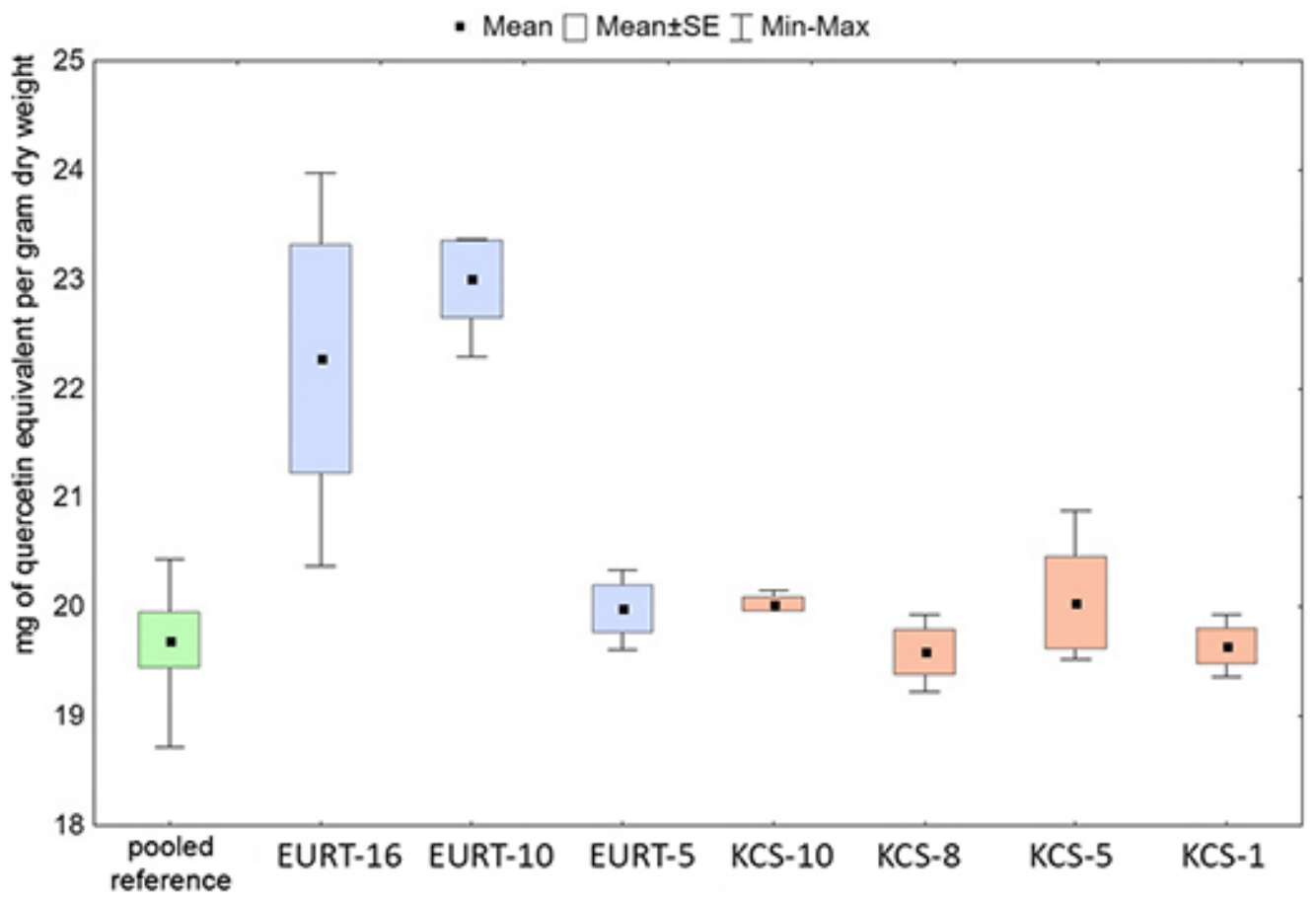

Fig. 4. Total low-molecular-weight antioxidants (mg of quercetin equivalent per gram dry weight) in P. major seedlings from different sites

PAI indices of the KCS samples and the reference ones ( $U$-test, $n=15-25, p=0.45-0.52$ ).

Additionally, the analysis of the total LMWA (Fig. 4) in the seedlings of $P$. major was carried out, which showed no differences between the pooled samples from different sites $\left(H_{(1-3 ; 6-12)}=2.33-4.85, p=0.067-0.183\right)$. However, there was a significant increase in the total LMWA in the EURT-16 and EURT-10 samples, and, thus, in the pooled EURT sample, there was an increase in this parameter compared to the KCS and reference sites $\left(H_{(2 ; 27)}=9.85, p=0.007\right.$; Dunn test, $p=0.013-0.038)$.

\section{Discussion}

Analysis of the results obtained and their comparison with the literature data show that the functioning of the antioxidant system components and their relationship with the rates of lipid peroxidation processes are regulated differently depending on the type of stressor affecting them (Polesskaya, 2007; Shimalina et al., 2017, 2018; Słomka et al., 2008; Sharma et al., 2012; Morozova et al., 2016). The antioxidant system response is determined by the degree and duration of exposure to the stress (Polesskaya, 2007).

Differences in the mechanisms of ROS induction by ionizing radiation and heavy metals may be the cause of dissimilar reactions. The major process in the generation of reactive oxygen species by ionizing radiation is water radiolysis, which results in formation of hydrated electrons, superoxide radical, hydroperoxyl, and hydrogen peroxide (Grodzinsky, 1989; Esnault et al., 2010).

Heavy metals increase the generation of ROS through direct and indirect mechanisms, such as direct transfer of electrons in oneelectron reactions; disturbance of metabolic pathways; displacement of irreplaceable cations from specific binding sites of enzymes and 
inhibition of enzymatic activity due to affinity of heavy metals to SH-groups of enzymes; depletion of the pool of low-molecular-weight antioxidants (Shahid et al., 2014). Redox-active metals such as iron and copper can generate ROS directly by participating in biological redox reactions such as the Fenton and Haber-Weiss reactions (Shahid et al., 2014). The differences between plant responses to stress may be caused by the dissimilar chemical properties and biological activities of different ROS types, which are involved in processes occurring in various signaling systems (Apel, Hirt, 2004).

In the present study, MDA content and CAT and SOD activities were increased but POX activity was decreased in P. major from the EURT site. Another study (Volkova et al., 2017) also showed a decrease in peroxidase activity in Pinus sylvestris L. seedlings from the Chernobyl NPP zone and a high level of oxidative stress. However, no differences in the activities of superoxide dismutase and catalase were observed in those samples compared to the reference ones. In Arabidopsis thaliana (L.) Heynh. from the same zone, the activity of guaiacol peroxidase increased in the shoots, while activity of catalase and ascorbate peroxidase considerably decreased with increasing radiation load (Morozova et al., 2016). Thus, adaptive responses of the antioxidant system to the effect of ionizing radiation vary widely across species. The ability of plants to maintain prooxidant/antioxidant balance under toxic stress is also species specific, as it was shown for Vicia cracca L. and Taraxacum officinale Wigg. (Savinov et al., 2007), for
Melilotus albus Merik. and Trifolium medium L. (Fazlieva et al., 2012).

One of the possible reasons for the diverse responses of plant antioxidant system to anthropogenic factors in nature may be the modifying effect of weather conditions (Pozolotina, Antonova, 2017). The ability of plants to tune their metabolism in a special mode, aimed at protecting them against excess ROS and associated oxidative stress, can be considered as a reaction developed during evolution that preserves the species potential for existence in adverse conditions.

\section{Conclusion}

The present study revealed the differences in the prooxidant/antioxidant balance of seed progeny of $P$. major from the sites with different types of anthropogenic contamination. Seedlings from the radioactively contaminated area exhibited a prooxidant shift: a higher content of malondialdehyde and an increased activity of superoxide dismutase (SOD) and catalase (CAT) compared to reference plants. In seedlings from the chemically contaminated area, the SOD and CAT activities were reduced compared to the reference sites, while the peroxidase activity was increased. Enhancement of antioxidant protection based on low-molecular-weight antioxidants was shown only in the East Ural Radioactive Trace samples. Results obtained in the present study indicate that dissimilarities in plant adaptive responses are caused by differences in the induction of reactive oxygen species under elevated ionizing radiation and under contamination by chemical toxicants.

\section{References}

Apel K., Hirt H. (2004) Reactive oxygen species: metabolism, oxidative stress, and signal transduction. Annual Review of Plant Biology, 55: 373-399

Buege J. A., Aust S.D. (1978) Microsomal lipid peroxidation. Methods in Enzymology. Vol. 52. Academic Press, p. 302-310 
Caplin N., Willey N. (2018) Ionizing radiation, higher plants, and radioprotection: from acute high doses to chronic low doses. Frontiers in Plant Science, 9: 847

Chernen'kova T.V. (2002) Response of forest vegetation to industrial pollution. Moscow, Nauka, 191 p. (in Russian)

Ermakov A.I., $\quad$ Arasimovich V.V., $\quad$ Yarosh N.P., $\quad$ Peruanskiy Y.V., $\quad$ Lukovnikova G. A., Ikonnikova M.I. (1987) Methods of biochemical research of plants. A. I. Ermakov (ed.) Leningrad, Agropromizdat, 429 p. (in Russian)

Esnault M.A., Legue F., Chenal C. (2010) Ionizing radiation: advances in plant response. Environmental and Experimental Botany, 68(3): 231-237

Fazlieva E. R., Kiseleva I. S., Zhuikova T. V. (2012) Antioxidant activity in the leaves of Melilotus albus and Trifolium medium from man-made disturbed habitats in the Middle Urals under the influence of copper. Russian Journal of Plant Physiology, 59(3): 333-338

Fischer B. B., Pomati F., Eggen R.I.L. (2013) The toxicity of chemical pollutants in dynamic natural systems: the challenge of integrating environmental factors and biological complexity. Science of the Total Environment, 449: 253-259

Garnier-Laplace J., Geras'kin S., Della-Vedova C., Beaugelin-Seiller K., Hinton T. G., Real A., Oudalova A. (2013) Are radiosensitivity data derived from natural field conditions consistent with data from controlled exposures? A case study of Chernobyl wildlife chronically exposed to low dose rates. Journal of Environmental Radioactivity, 121: 12-21

Giannopolitis C.N., Ries S.K. (1977) Superoxide dismutases: I. Occurrence in higher plants. Plant Physiology, 59(2): 309-314

Goth L. (1991) A simple method for determination of serum catalase activity and revision of reference range. Clinica Chimica Acta, 196(2-3): 143-151

Grodzinsky D. M. (1989) Plant Radiobiology. Kiev, Naukova Dumka, 384 p. (in Russian)

Gudkov S. V., Grinberg M.A., Sukhov V., Vodeneev V. (2019) Effect of ionizing radiation on physiological and molecular processes in plants. Journal of Environmental Radioactivity, 202: $8-24$

Karimullina E.M., Mikhailovskaya L.N., Antonova E. V., Pozolotina V.N. (2018) Radionuclide uptake and dose assessment of 14 herbaceous species from the East-Ural radioactive trace area using the ERICA Tool. Environmental Science and Pollution Research, 25(14): 13975-13987

Khramova E.P., Tarasov O.V., Krylova E.I., Syyeva S.Y. (2006) Peculiarities of flavonoid accumulation in plants in conditions of radiation contamination. Journal of Radiation Safety Issues [Voprosy radiacionnoi bezopasnosti], 4: 13-21 (in Russian)

Kruger N. J. (2009) The Bradford method for protein quantitation. The protein protocols handbook. New York, Humana Press, p. 17-24

Molchanova I., Mikhailovskaya L., Antonov K., Pozolotina V., Antonova E. (2014) Current assessment of integrated content of long-lived radionuclides in soils of the head part of the East Ural Radioactive Trace. Journal of Environmental Radioactivity, 138: 238-248

Møller A.P., Mousseau T.A. (2015) Strong effects of ionizing radiation from Chernobyl on mutation rates. Scientific Reports, 5: 8363

Morozova V.S., Kashparov V. A., Levchuk S. Y., Umanska A. O., Bishchuk Y. V., Otreshko L. M. (2016) The functional state of cellular antioxidant defence system of shoots of Arabidopsis thaliana 
exposed to the chronic ionizing radiation in the Chornobyl exclusion zone. Nuclear Physics and Atomic Energy, 17(3): 302-307

Nikipelov B. V., Mikerin E. I., Romanov G. N., Spirin D. A., Kholina Y.B., Buldakov L. A. (1990) The radiation accident in the Southern Urals in 1957 and the cleanup measures implemented. Recovery operations in the event of a nuclear accident or radiological emergency. International Atomic Energy Agency, Vienna, p. 373-403 (in Russian)

Ontogenetic atlas of medicinal plants (1997) Zhukova L.A. (ed.) Yoshkar-Ola, Mari State University, 240 p. (in Russian)

Polesskaya O. G. (2007) Plant cell and reactive oxygen species. Moscow, KDU, 140 p. (in Russian)

Popov T., Neǐkovska L. (1971) Method of determining the peroxidase activity of blood. Hygiene and Sanitation [Gigiena i Sanitariya], 36(10): 89-91 (in Russian)

Pozolotina V.N., Antonova E. V. (2017) Temporal variability of the quality of Taraxacum officinale seed progeny from the East-Ural radioactive trace: is there an interaction between low level radiation and weather conditions? International Journal of Radiation Biology, 93(3): 330-339

Pozolotina V.N., Antonova E.V., Bezel V.S. (2012) Comparison of remote consequences in Taraxacum officinale seed progeny collected in radioactively or chemically contaminated areas. Ecotoxicology, 21(7): 1979-1988

Pozolotina V.N., Antonova E. V., Shimalina N. S. (2016) Adaptation of greater plantain, Plantago major L., to long-term radiation and chemical exposure. Russian Journal of Ecology, 47(1): 1-10

Savinov A.B., Kurganova L.N., Shekunov Y.I. (2007) Lipid peroxidation rates in Taraxacum officinale Wigg. and Vicia cracca L. from biotopes with different levels of soil pollution with heavy metals. Russian Journal of Ecology, 38(3): 174-180

Shahid M., Dumat C., Pourrut B., Sabir M., Pinelli E. (2014) Assessing the effect of metal speciation on lead toxicity to Vicia faba pigment contents. Journal of Geochemical Exploration, 144: $290-297$

Sharma P., Jha A.B., Dubey R.S., Pessarakli M. (2012) Reactive oxygen species, oxidative damage, and antioxidative defense mechanism in plants under stressful conditions. Journal of Botany, 2012: 217037

Sharma R.K., Agrawal M. (2005) Biological effects of heavy metals: an overview. Journal of Environmental Biology, 26(2): 301-313

Shimalina N. S., Pozolotina V. N., Orekhova N. A., Antonova E. V. (2017) Assessment of biological effects in Plantago major L. seed progeny in the zone of impact from a copper smelter. Russian Journal of Ecology, 48(6): 513-523

Shimalina N. S., Orekhova N. A., Pozolotina V.N. (2018) Features of prooxidant and antioxidant systems of greater plantain Plantago major growing for a long time under conditions of radioactive contamination. Russian Journal of Ecology, 49(5): 375-383

Słomka A., Libik-Konieczny M., Kuta E., Miszalski Z. (2008) Metalliferous and non-metalliferous populations of Viola tricolor represent similar mode of antioxidative response. Journal of Plant Physiology, 165(15): 1610-1619

Smorkalov I. A., Vorobeichik E.L. (2011) Soil respiration of forest ecosystems in gradients of environmental pollution by emissions from copper smelters. Russian Journal of Ecology, 42(6): 464-470 
Stepanov A. M., Kabirov R.R., Chernen'kova T.V., Sadykov O.F., Khanislamova G. M., Nekrasova L.S., Butusov O.B., Baltsevich L.A. (1992) Integrated ecological assessment of technogenic impact on ecosystems of southern taiga. CEFP, Moscow, 246 p. (in Russian)

Titov A. F., Kaznina N. M., Talanova V.V. (2014) Heavy metals and plants. Petrozavodsk, KSC RAS, 194 p. (in Russian)

Volkova P.Y., Geras'kin S.A., Kazakova E.A. (2017) Radiation exposure in the remote period after the Chernobyl accident caused oxidative stress and genetic effects in Scots pine populations. Scientific Reports, 7: 43009

Zvereva E.L., Roitto M., Kozlov M.V. (2010) Growth and reproduction of vascular plants in polluted environments: a synthesis of existing knowledge. Environmental Reviews, 18: 355-367 